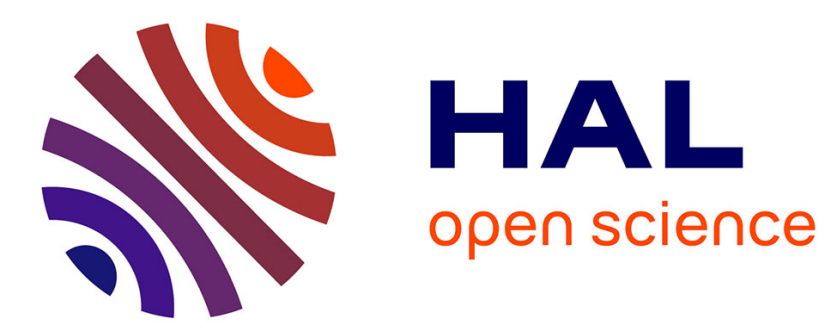

\title{
Struggles of Citizenship in the Maghreb
}

Delphine Perrin

\section{- To cite this version:}

Delphine Perrin. Struggles of Citizenship in the Maghreb. Routledge. The Routledge Handbook of

Global Citizenship Studies, pp.230-239, 2014, 10.4324/9780203102015.ch19 . hal-01395220

\section{HAL Id: hal-01395220 \\ https://hal-amu.archives-ouvertes.fr/hal-01395220}

Submitted on 10 Nov 2016

HAL is a multi-disciplinary open access archive for the deposit and dissemination of scientific research documents, whether they are published or not. The documents may come from teaching and research institutions in France or abroad, or from public or private research centers.
L'archive ouverte pluridisciplinaire HAL, est destinée au dépôt et à la diffusion de documents scientifiques de niveau recherche, publiés ou non, émanant des établissements d'enseignement et de recherche français ou étrangers, des laboratoires publics ou privés. 


\section{Struggles of Citizenship in the Maghreb}

\section{Delphine Perrin}

Key terms:

Double ius soli: Access to citizenship through birth in a country and the mother or father's birth in the country.

Triple ius soli: Access to citizenship through double ius soli and a grand-parent's birth in the country.

Co-ethnic provision: Provision, which links access to citizenship to ethnic characteristics supposedly shared in the country.

\section{Introduction}

Although citizenship is a fundamental issue in postcolonial states, it has been hardly discussed within the Maghreb countries ${ }^{\mathrm{i}}$ since independence and until recently. Citizenship regulations were among the first legal texts to be adopted after independence. ${ }^{\text {ii }}$ Yet, they were subject to very few changes in the decades afterwards. This legislative stability has to be seen together with the strength of political regimes and elites in the region. It reflects not only a lack of democracy but also weakness in national questioning and difficulties in state building.

During the last decade however, a wave a legal reforms has affected the Maghreb and 
led to unprecedented reforms of citizenship laws in the five countries. This was mainly inspired by the struggle of women for their rights at the regional and national levels, which led to revise legislation in Egypt in 2004, then in Algeria (2005), Morocco (2007), Tunisia (2010) and Libya (2010), and, on different grounds, in Mauritania (2010).

Very few studies have been undertaken on citizenship in Maghreb countries. Those studies mostly address the problematic of citizenship through what might be called an essentialist orientalism, through the Arab identity of the Maghreb countries, and their belonging to the Middle East as a whole (Belkziz 1967; Parolin 2009; Butenshon and Co 2000). They are thus studied as part of the Arab and Muslim world, without any kind of sub-regional specificity. Country-by-country approaches are also scare, save in the case of Algeria. Because of its traumatic road to independence and its obsessive relationship with France, Algeria's attitude to citizenship after decolonization has been quite extensively studied by French and Algerian-French scholars (Etienne 1968; Mahiou 2005; Le Foll-Luciani 2012; Hosna 2007).

Two approaches have so far limited the relevance of studies about the Maghreb countries. First, there is the essentialist approach which consists in interpreting their law mainly if not exclusively as dictated by Islam and a sui generis pre-colonial identity. It tends to ignore the political use and construction of ethno-religious determinants by the colonial powers during colonization and by the subsequent regime after independence. Maghreb regimes themselves have indeed provided the necessary material for an essentialist approach by imposing a uniform conception of the nation, considered as homogeneously Arab and Muslim, and by denying any diversity or alternative identity within the population. A second approach has consisted in interpreting the law in the 
Maghreb as a continuation or a transposition of the former colonial power's legal order. The five Maghreb countries were, indeed, all colonized: Morocco and Mauritania by Spain and France, Tunisia and Algeria by France and Libya by Italy. An impact of the colonial powers on their law and practice has thus been observed but also presumed. Like the first, this second approach tends to ignore the diversity of regulations across the Maghreb, the specificity of each national route and the legal creativity of the different regimes. Those two approaches are turned to the past and based on the conception of a transhistorical and steady identity in the region, an identity which only colonization would have subverted. Yet, the last decade's debates and reforms have highlighted the topicality of the struggles of citizenship - struggles that had been hidden for years and which have recently found the opportunity to emerge. Today, expatriates, women, and other parts of the Maghrebian populations, including Berbers, claim their recognition and their rights as full citizens.

\section{The relevance of an essentialist approach to citizenship}

The five Maghreb countries are considered as Arab and Muslim countries and were all once colonies. Citizenship is said to have been the creation of colonial powers, since the express notion of citizenship was first used in reference to the foreign presence in the territory. This form of citizenship, linking the state to the individual, is considered as distinct from an irreducible pre-colonial identity based on religion.

\section{Colonial inheritance}

Unlike in Europe where sovereignty was primarily territorial, political power in North 
Africa was established through personal allegiance to authority. In the Western Sahara case before the International Court of Justice (ICJ) ${ }^{\mathrm{iii}}$, Morocco claimed a pre-colonial sovereignty over this area. Rabat argued that its special character was based on the fact that its people were united by the common religious bond of Islam and the allegiance of the various tribes to the Sultan, rather than by territorial notions (Perrin 2011b: 6). Consequently, 'state' organisation was not based on sovereign control over a territory, but on a personal oath to the Sultan as the Commander of the Faithful. Power links depended on Islam, and Arabic became the official national language of the Sherifian Kingdom. There was no strict definition of a citizen, independent of religion. Likewise, at independence, Algerian nationalists invoked the existence of an Algerian nation in the pre-colonial era, based on the religious bond of Islam. The Arabic language, repressed during colonization, was presented as a second pillar of Algerian citizenship (Hosna: 4).

During the French Protectorate in Morocco, as during French colonization in Algeria, the necessary distinction between settlers and natives relied on ius soli (the Indigenous) and ius religionis - which also enabled to separate Muslims and Jews among the Indigenous (Hosna: 6).

Decolonization sometimes led to reactions in the immediate post-independence era. Some provisions adopted in the first citizenship regulations certainly reflected a concern vis-à-vis the former colonists and tended to prevent former colonials or those who supported them from becoming nationals, but this position was not commonly shared by the Maghreb countries.

Rejection was most obvious in Algeria. Some Europeans and some Jews of Algeria naturalized French by the 1870 Décret Crémieux - had fought for independence and 
stayed in Algeria after the departure of the colonial power. However, a circular of 9 May 1963 relating to the application of the Code of Algerian Citizenship defined 'Algerian of origin' as referred to in the Code, as being a person who has at least two ascendants in paternal lineage born in Algeria with the Muslim status. The provision was thus based on the discrimination established by the former colonists between the status of Indigenous and the French, and it effectively excluded non-Muslims from the new nation. These 'externals' could apply for Algerian citizenship on the basis of their participation to the liberation struggle. Yet, most were upset at being excluded in such a way and held back from doing so (Le Foll-Luciani: 6). Only French nationality was thus offered to them, since the Accords d'Evian of 18 March 1962 had given Europeans in Algeria three years to opt between the French or Algerian citizenship. In Morocco, the 1958 citizenship Code retained the double ius soli introduced during the French Protectorate. However, to prevent colonial descendants from benefiting from this provision, a temporal limit was introduced. Consequently, children born in Morocco to foreign parents also born there could become Moroccans only if their parents were born after independence. But no time-limit was placed on double ius soli when applied to Arab-Muslim descendants. Indeed, a person born in Morocco to a foreign father also born there at any time could become Moroccan, if the father came from a country where the majority of the population practiced Islam and spoke Arabic, and if he belonged to this community. This provision aimed, at independence, at incorporating nationals of Algerian origin who were numerous to live and work in Morocco. Combined with the previous provision, it also hindered access to citizenship for those from colonial lines, to favour national unity based on shared values. This atypical co-ethnic provision can be found in Egypt too. It is close to some equivalents in 
Africa, in Mali for instance, where co-ethnicity is based on African origins. The two forms of ius soli mentioned above, and thus the possibility of integrating thirdgeneration foreign nationals was retained in the 2007 Moroccan reform. ${ }^{\text {iv }}$ In Tunisia, ius soli only applies to the fourth generation, in paternal descent, born in the country, and a repudiation right is offered to persons born before 1963.

Until recently, Mauritanian legislation was particularly inspired by the French system and enabled the integration of second and third generation non nationals. The 2010 reform, in some senses, decolonized citizenship law and affected the forms of ius soli that were inherited from the colonization. The revision removed two major forms of ius soli from the previous law and reduced the scope of a third form. The provision enabling children born in the country to foreign parents to opt for citizenship when they come of age, as long as there had been a five-year residency, was suppressed. Similarly, any foreign national born in the country, who previously had been able to apply for naturalization without any previous residency requirement, has now to demonstrate a five-year residency. Mauritania used to grant nationality of origin through double ius soli, a form of granting which disappeared with the reform. Actually, the revision was less inspired by an intention to decolonize law than by a will to reduce the scope of integration of persons likely to be considered as aliens in a nation where ethno-cultural diversity is an issue.

It has to be noted that the automatic acquisition of nationality at birth via double ius soli, which had appeared during the colonization, ${ }^{\mathrm{V}}$ was then retained at independence in Algeria, Morocco and Mauritania, all of them former French colonies or protectorates. Yet, double ius soli was removed in Algeria seven years later, in 1970 (Mahiou 2005: 
400), and in Mauritania in 2010, as if this colonial legacy could not fit these countries' national interests. Being a former French colony, Tunisia never opted for the double ius soli.

Today, there is hardly any colonial legacy and Maghreb-wide features based on a formerly-shared colonial power. Some features are shared by two or more states, like Mauritania and Tunisia in their gender approach, or by Algeria and Libya through the lack of ius soli. The absence of regional model is illustrated by the fact that some features are shared by only some countries of the area. It is also reinforced by the fact that some provisions or approaches are found in one Maghreb country and then also a country outside this area, to the exclusion of other Maghreb states. This is for instance the case with Morocco which shares its co-ethnic double ius soli provision with Egypt alone. This is also the case with Libya whose ethnic approach makes it be closer to Syria and Jordan than to its Maghreb neighbours.

The diversity of citizenship laws in the Maghreb goes beyond, then, a shared colonial past and shared colonial boundaries. It seems also to go beyond the shared Muslim and Arab identity, which is emphasized in the five Maghreb states.

\section{Arabness and Muslimness}

Muslim identity is proclaimed in the constitutions of the five Maghreb countries, as well as belonging to the Arab world. These states define themselves as Muslim countries, belonging to the Great Maghreb, with Arabic as their official language. The Maghreb is said to associate Islam and Arab identity together and to ideologically link Muslimness 
and Arabness (Chaker 2012: 118). This leads to the negation of other identities, such as Berber Muslims, Arab Christians or Jewish Maghrebians.

The gender discrimination which has affected citizenship laws, and especially the scope of ius sanguinis in the Maghreb is not specifically based on Islam. Gender discrimination was widespread till the middle of the XXth century. It was inspired by patriarcal values common to monotheistic religions. When the first texts on citizenship were adopted in the Maghreb, ius sanguinis was exclusively paternal. This was in line with a regional, if not a global, trend since women had not yet gained equality in terms of citizenship-related rights in many parts of the world, including in Europe and notably in the former colonial powers. ${ }^{\text {vi }}$ The extent of gender discrimination varies greatly from one Maghreb country to the other and has been recently reduced.

Though mentioned in constitutions from the region, religion is quasi-absent from citizenship laws. Yet, in practice, it may be important in getting citizenship through naturalization and marriage.

Likewise, being an Arab is not a legal condition for citizenship, but it can facilitate access to citizenship. It is emphasized through the requirement to speak Arabic in order to be naturalized, except in Mauritania where speaking one out of three other languages listed in the law can enable a naturalization.

Moreover, two national specificites are worth mentioning: the co-ethnic provision in Morocco already referred to above, which provides for a specific and preferential way to get citizenship for Arab-Muslim fellows; the pro-Arab approach in Libya, which provided Arabs with privileges in their access to citizenship. Law n ${ }^{\circ}$ 8/1980 entitled 'Libyan Arab citizenship' added facilitations for Arabs wanting to become Libyan citizens to facilitations already provided in the 1954 citizenship law. Still, law $n^{\circ} 456$ of 
1986 also gave Arab nationals the same rights and duties as nationals if they decided to live in Libya without any need to become a Libyan national. The 2010 reform put an end to the positive discrimination in favour of Arabs.

It is to be noted however that, even though they are Arabs, Palestinian nationals are not necessarily naturalized in Maghreb countries, which may avoid granting them citizenship, in accordance with the League of Arab States' 1965 Casablanca Protocol for the treatment of Palestinians in Arab states. The latter prescribed the grant of citizen rights without citizenship. In Libya, Palestinians were not naturalized and Palestinian women married to Libyan males were not granted citizenship, in exception to the provision applied to foreign women married to nationals. In July 2005, Mahmoud Abbas declared that the naturalization of Palestinians abroad would not be looked upon badly by the Palestinian Authority. Then, in October 2009, the Algerian Minister of Justice declared $^{\text {vii }}$ that Palestinians constituted the second largest national group, after French citizens, to have obtained Algerian citizenship since 1970.

Algerians in Morocco or Moroccans in Algeria have also suffered from the consequences of troubled relations between neighboring states. After the Algerian 'Black Walk' following the Moroccan 'Green Walk' in 1975, King Hassan II reacted to the expulsion of Moroccan citizens from Algeria and requested that his administration treat Algerian applications to naturalization with circumspection. Yet, out of the 1,646 persons who obtained Moroccan nationality between 1959 and 2007, 62 per cent were Algerians. ${ }^{\text {viii }}$ The great majority of applicants to Algerian citizenship are Moroccan citizens living in Algeria and working in Algerian companies. However, according to the Algerian Ministry of Justice, the most numerous nationalities to be naturalized are the French followed by Palestinians, Syrians, Egyptians, Iraqis, Tunisians and some 
Sub-Saharan citizens. These applicants were, if not all Arab, then at least Muslim. Finally, an ethnic approach is not necessarily based on Arab ethnicity. Granting citizenship is often a political gesture, intimately linked to interstate relations and national balances. This was particularly true when Libya offered citizenship in the 1980s to a number of (Berber) Tuaregs from Mali and Niger (Boilley 1999: 433), even if Gaddafi persisted in assimilating Berbers and Arabs.

While express mentions of Arab ethnicity or Islam are scarce on the books, they seem to be important criteria when granting citizenship. Access to citizenship in the Maghreb is, in any case, reputed to be long, difficult and uncertain. The difficulty is not due to the legal criteria for naturalization that are, for the most part, quite reasonable. ${ }^{\text {ix }}$ It is not due either to many requests made for citizenship. Reluctance to grant citizenship is rather based on a mix of immaturity in nation-building, of a closed and 'naturalist' - if not ethno-religious - conception of the nation, of suspicion and fear toward difference and aliens. Yet, the rejection of diversity has recently been questioned.

\section{The struggles of citizenship today}

It is striking that, unlike other countries in the Middle East, with the exception of Egypt, Maghreb states all reformed their citizenship laws during the last decade, between 2005 and 2010. These reforms are part of an unprecedented legal development in the region and are linked to revisions in related fields such as immigration (2003 in Morocco, 2004 in Tunisia, 2008 and 2009 in Algeria, since 2008 in Mauritania, 2004, 2005 and 2010 in Libya) and family (1993 in Tunisia, 2001 in Mauritania, 2004 in Morocco and 2005 in Algeria). 
Those reforms that preceded the 'Arab Spring' saw development in terms of democracy and the rights of citizens, mainly women and dual nationals, as well as an openness toward diversity. The 2011 uprisings accompanied and confirmed the call for diversity and for the extension of individual rights. They have resulted in or they may result in new changes affecting citizenship, insofar as some legal changes tend to improve women's rights, include the diaspora abroad and recognize diversity in the nation.

\section{Extending Women's Rights}

Except in Mauritania, the latest reforms of citizenship laws in the Maghreb have improved women's rights, and, by extension, children's rights. Ius sanguinis was initially exclusively paternal, which means that only the father passed his citizenship on to his children and wives.

Tunisia and Mauritania were the first states in the region to change this situation in the 1960s, when they recognized a mother's right to transmit citizenship to children born to foreign fathers. Yet, gender equality was not full even in these cases. The transmission of citizenship was automatic only when the child was born in the country. Ius soli was thus an additional necessary condition to female ius sanguinis. In Morocco, Algeria and Libya, children born to a national mother and a foreign father remained aliens in their own country until they came of age. The transmission of the mother's citizenship was possible only when the father was unknown or stateless, to avoid statelessness. In response to an international campaign for 'Arab Women's Right to Citizenship' and equivalent national campaigns, four out of the five Maghreb countries followed the 2004 Egyptian precedent and revised their legislation. Algeria, Morocco, Tunisia and 
Libya reformed their regulations to enable women to transmit citizenship to any children born to a foreign father. Yet, only Algeria and Tunisia now offer strict equal rights between men and women in this regard. Mauritania is in fact behind its neighbors in terms of equality now, since a child born abroad to a Mauritanian mother does not get citizenship unless a specific declaration is made. In 2010, Tunisia removed this discriminatory provision, while Mauritania has maintained it despite further reforms in the same year. Even when born in Mauritania, children of Mauritanian women have the right to repudiate their citizenship upon declaration at age, unlike children of Mauritanian fathers who are subject to another procedure if they want to lose Mauritanian citizenship. In its 2007 reform, Morocco opted for the Mauritanian model, by giving the opportunity to children born to a foreign father to repudiate their mother's Moroccan citizenship when they come of age, unlike children born to a Moroccan father. It is unclear if Libya has actually changed the legislation. The Libyan reform, indeed, submits the mother's right to pass her citizenship to her children born to a foreign father to the authorities' approval. Besides, the legislative reform still has to be specified in executive texts.

Only in Algeria, can women pass their citizenship on to a foreign husband. Indeed, a male foreign national can apply for Algerian citizenship after three years of marriage to an Algerian woman, as can a female alien married to an Algerian man. ${ }^{\mathrm{x}}$ In the other Maghreb countries, gender discrimination is applied with regard to foreign nationals' access to citizenship through marriage to a national. Foreign women are subject to a specific procedure related to marriage, while foreign men have to follow the naturalization process. The latter will benefit from facilitations in Tunisia, Mauritania 
and Libya, while in Morocco, marriage may be considered as an element showing integration to be taken into account in naturalization.

The 2007 Moroccan reform was closely connected to the 2003 reform of migration law and revealed a reluctance to accept mixed marriage. It extended the probationary time needed for a resident foreign woman married to a Moroccan citizen. This period, required before any submission for Moroccan citizenship is allowed, rose from two to five years, i.e. equal to the period required for general naturalization. Foreign nationals wishing to obtain Moroccan citizenship are now subject to the same residency requirement be they men or women, though not the same procedure. The government claimed here to be combating marriages of convenience, given a recent increase in the number of mixed couples.

Mauritania also extended the probationary time needed for a foreign woman married to a citizen before getting citizenship, from immediate citizenship to a five-year wait for the same, i.e. equal to the period now required from foreign males and females married to national citizens in conformity with the Chariaa to obtain their naturalization. It is thus to be noted that access to citizenship through marriage to a national has been lengthened for women as for men, the latter could previously have been naturalized without any pre-residency requirement. Besides, a specific procedure is maintained for foreign women marrying a national in addition to the now un-gendered naturalization process.

There is still a long way to go before women obtain full equality as far as citizenship is concerned and this uncompleted struggle has been revived by the events of 2011. Yet, these reforms have improved women's rights and are a sign of acceptance of diversity 
in society, since the children born to mixed couples are now considered nationals. Consequently, the number of dual nationals will considerably rise in the region.

\section{Including the Diaspora}

Because of difficulties in nation-building and sensitivity in issues of belonging, the Maghreb countries have looked upon dual citizenship and expatriation with suspicion. At independence, Tunisia and Mauritania opted for the principle of disallowing multiple allegiances, which was removed in Tunisia in 1975 and which has just been suppressed in Mauritania. With its 2010 reform, Mauritania has thus accepted dual citizenship for its nationals, responding to a long-standing popular claim and an already widespread practice. Morocco and Algeria have never required their nationals to choose between Moroccan/Algerian citizenship when getting another citizenship. Besides, Algeria removed in 2005 the requirement that new citizens discard their older citizenship in order to become Algerian citizens, a requirement that had been introduced in 1970 (Mahiou: 395-407). The absence of any prohibition does not necessarily mean the acceptance of dual citizenship, however. Algerian President Bouteflika has always been hostile toward it. When the citizenship law was reformed in 2005, he announced that dual nationals would be treated as aliens in Algeria and he threatened to adopt Mauritanian regulation which was at that time based on a single allegiance. Bouteflika was here reacting to an announcement of the French Consul in Algiers, who in 2005 stated that about 100,000 Algerian requests had been made to 'reintegrate' French citizenship. This is, indeed, an Algerian specificity: its nationals benefit from

possibilities inherited from colonization to 'reintegrate' French citizenship. ${ }^{\mathrm{xi}}$ The 
Algerian-French dual citizenship is not only linked to immigration in France. It is also widespread among residents in Algeria, who are attracted by opportunities that this second citizenship may offer, above all in terms of mobility.

Yet, dual citizenship is not compatible with some important offices. Candidates to the Presidency of the Algerian Republic and their wives shall be exclusively Algerian, as shall people in charge of the main executive positions in the country. In Tunisia, candidates to the Presidency had to have only Tunisian citizenship, Islam as their religion, with their father, mother and grandparents being Tunisian. Things have changed since Moncef Marzouki, the provisional President in Tunisia since the 2011 uprising and a former expatriate in France, is a dual citizen.

Algeria has developed more than its neighbors the rights of its diaspora, not least through the organization of elections abroad. In Morocco, while multi-allegiance is not officially criticized, being an expatriate leads to obstacles to participation in the political life of the country. Voting rights for all citizens was guaranteed by the 1962 constitution. However, it had never been implemented for expatriates, with the exception of the 1984-1992 period when Moroccans residing abroad (MRAs) were represented in the Parliament by five representatives. Mohamed VI launched a royal initiative in 2005 asking the government to restore the full citizenship of MRAs, who account for around three million people, representing some 10 percent of the population. Law n²3-06 has enabled young Moroccans born abroad to be registered on electoral lists in Morocco in order to vote and be elected. So far, the theoretical right has been recognized, but it has not been implemented in practice. This reveals the uneasy relations between Morocco and its expatriates. While a Consultative Council of Moroccans Abroad was created, in 2007, to strengthen the link between the Sherifian 
Kingdom and its diaspora, the government remains suspicious of Moroccans residing abroad and of their potential for destabilization. Yet, the 2011 reform of the constitution stipulates that Moroccans residing abroad shall benefit from full citizenship rights, including the right to vote and to be elected in local, regional and national elections. This has been seen as an important sign of openness, together with further recognition of diversity in the nation.

\section{Recognizing Diversity in the Nation}

The reforms that preceded the 'Arab Spring' constituted a first step in the recognition of diversity that had been a fundamental failure of Maghrebian states. As mentioned above, these states have opened the nation to mixed couples' offspring. The 2011 social movements have given other formerly hidden categories of the population the opportunity to claim their rights. This is the case with Berbers, who had suffered from Arabization policies introduced in Morocco and Algeria in the $1960 \mathrm{~s}^{\mathrm{xii}}$, and from the denial of their existence in Libya. Even in the post-Gaddafi era, the acknowledgement of Amazigh culture and identity in the constitution is still considered by many as a threat to Arab authority and control in the region, and subsequently as a threat to the existence of Arab identity and culture (Eljarh M. 2012). In the Maghreb as a whole, the social movements have been qualified as 'Arab Spring' and the new leaders in Libya and Tunisia referred to the Arab Maghreb which they suggested to revive. While Berbers are still struggling in Libya, where there have been demonstrations demanding that the new constitution recognize Amazigh culture and Tamazight as Libya's second language, they have obtained an unedited recognition in Morocco. 
Indeed, the new Moroccan constitution now recognizes Tamazight as an official language of the Kingdom, next to Arabic. This is a fundamental step, ten years after Mohamed VI had started a policy recognizing the Berbers' cultural rights. In contrast, there has been no change in Algeria, where non Arab-Muslim names are still forbidden, ${ }^{\text {iii }}$ although the Imazighen have been struggling against the state for more than ten years and have seen their language be recognized as a national language. While Morocco's new constitution preamble now defines its components as being 'Arab-Islamic, Amazigh and Saharan-Hassani', Mauritania has recently confirmed an Arabizing turn undertaken for more than a decade. The list of national languages mentioned in its constitution was changed in 1991. The languages listed in the citizenship law was also modified in 2010, in conformity with the constitution, and reduced from seven to four languages. This has resulted from rationalization as well as amputation. The former list included Arabic, Toucouleur, French, Saracollé, Wolof, Bambaria and Hassani. In the new list, Saracollé and Toucouleur have disappeared but remain recognized under another form, since Pulaar and Soninké have been added to Arabic and Wolof. French, Bambara and Hassani have been simply suppressed, which confirms the 'decolonizing' intention. It also shows that Bambaras have been unable to obtain the recognition of their identity, unlike the Pulaar, Soninké and Wolof. ${ }^{\text {xiv }}$ Moreover, it is interesting to note the removing of Hassani, in the constitution and the new citizenship law, a language spoken in Mauritania, in the Western Sahara and in the south of Morocco, whereas Morocco has introduced in its new constitution a provision aiming at protecting it. Here, the diversity of the Mauritanian population and of its origins is questioned. The 2010 reform of the citizenship law was arguably adopted to prepare the 2011 census of the population, which revived the debates about Mauritanité. 
While the census sought to better distinguish aliens and nationals after citizenship rules had been refined, it led to tensions and questions about the status of the so-called Negro-Mauritanians and their assimilation to nationals from neighboring states. The issue of equality between Mauritanian citizens rose in parallel with the issue of the treatment of foreign nationals living in the country. The census raised strong reactions among the black Mauritanian population, whose members claimed that there was an attempt underway to remove their citizenship. A 'don't touch to my citizenship' movement was created to denounce any questioning of the citizenship of a part of the population through discriminating requests for evidence of their belonging to the Mauritanian nation. Be these allegations justified or not, the reform of the citizenship law unquestionably reflects closure with the restriction of the scope of ius soli without any extension of ius sanguinis. Unlike other Maghreb states which have recently developed an awareness of diversity in their societies, Mauritania has been evolving toward the refusal of the historical cultural mix of its population.

\section{Conclusion}

Citizenship in the Maghreb has recently seen significant progress, as an anticipation and a component of the 2011 upheavals. Progress in individual rights has resulted from the collective struggles of concerned groups: women, expatriates, cultural minorities. The few reforms adopted before and after the 2011 movements have not ended the struggles.

On the contrary, women, Berbers and other 'communities' feel even more legitimate and determined to change things, to have their society open up and to walk toward more inter-citizen equality, which is seen as an avatar of the key value of the 2011 upheavals: dignity. 
The five Maghreb countries are still closed societies and new tensions have also arisen, in parallel with the development of citizens' rights. A more recent 'other', the immigrant, has now become the object of negation and rejection. ${ }^{\mathrm{xv}}$ Racism is embedded in Maghreb societies which still deny it. Immigrants are not sufficiently organised yet to defend their rights, but a civil society in relation to immigrants has been progressively growing, mainly in Tunisia and Morocco, and will surely lead to the development of their rights.

\footnotetext{
i This Chapter will address the five members of the Arab Maghreb Union: Libya, Algeria, Tunisia, Morocco and Mauritania.

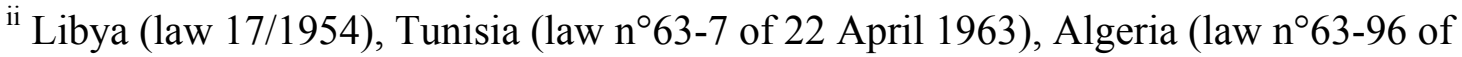
27 March 1963), Morocco (Dahir n¹-58-250 of 12 September 1958), Mauritania (law $\mathrm{n}^{\circ} 1961-112$ of 13 June 1961; law n 1962-157 of 15 August 1962).

iii Western Sahara, ICJ, advisory opinion, Rec.1975.

${ }^{\text {iv }}$ It is noteworthy that the 2007 Moroccan reform has added a residency requirement to
} the double ius soli, and put an emphasis on the link, which has to be real, between the individual and the Moroccan territory, rather than on exclusive descent. In both cases of double ius soli, the applicant has to have his/her main and regular residency in Morocco.

${ }^{\vee}$ Introduced in Europe by France in 1851. It was only paternal. It was adopted in Spain in 1954.

${ }^{\text {vi }}$ The 1803 French civil code granted French nationality at birth only to a child born to a French father. Women had been able to pass their citizenship to their children since 1927 but total gender equality was adopted only in 1973. In Spain, though the 1889 Spanish civil code provided that persons born to a Spanish father or mother would be 
Spanish even if they were born abroad, only single mothers could indeed pass their nationality. Born to a foreign father and a Spanish mother, the child was foreign. This changed in 1931 with women being able to keep their nationality even when married with a foreign national, but discrimination was restablished in 1954. It was only in 1982 that total gender equality was reached. In Italy, this gender equality was adopted in 1983.

vii Algerian Minister of Justice, www.mjustice.dz, 21 October 2009.

viii Moroccan Minister of Justice, M. Bouzoubaâ (2007) REMALD (Revue marocaine d'administration locale et de développement) 178: 70.

${ }^{i x}$ The minimum residency requirement is for five years in Morocco and Tunisia and for seven years in Algeria. The 2010 Mauritanian reform doubled the residency condition, raising it to ten years, as is the case in Libya.

${ }^{\mathrm{x}}$ Yet, a Muslim woman is still constrained to marry a Muslim man, according to family law.

${ }^{x i}$ French Civil Code, Chapter VII 'Des effets sur la nationalité française des transferts de souveraineté relatifs à certains territoires'.

xii These policies were aimed at the spread of the use of Arabic by the suppression of French and other local languages such as colloquial Arabic and Tamazight. xiii Since 1981. In Morocco, they have been forbidden since 1996 but should be authorized after the constitutional reform. See Human Rights Watch's letter to Morocco Interior Minister on the refusal of Amazigh names in 2009, http://www.hrw.org/node/85427

xiv There is an 'association for the Reawakening of Pulaar in Mauritania', a 'Mauritanian association for the promotion of Soninké language and culture', an 
'association for the promotion of the Wolof language in Mauritania' and a

'Coordination for the promotion of Bambaras in Mauritania'.

${ }^{\mathrm{xv}}$ See the cover of the Moroccan magazine Maroc Hebdo in November 2012 entitled 'the Black Peril'.

References:

Belkziz A. (1967), La nationalité dans les pays arabes, Rabat: éd. Cahiers de l’Université de Mohamed V

Bensaâd A. (ed.) (2011), Mauritanie, pays-frontière et pays-pont. Circulations migratoires, échanges et brassages, Paris: Karthala

Bruno E. (1968), Les problèmes juridiques des minorités européennes au Maghreb, Paris: Éditions du CNRS

Butenschon N. A., Davis U. and Hassassian M. (eds.) (2000), Citizenship and the State in the Middle East. Approaches and applications, , Syracuse: Syracuse University Press Chaker S. and Ferkal M. (2012), 'Berbères de Libye : un paramètre méconnu, une irruption politique inattendue', Politique africaine, $\mathrm{n}^{\circ} 125$ pp. $105-126$

Eljarh M. (2012), ‘Amazigh in Libya: from Gaddafi’s Denial to New Libya’s Crippling Silence', Middle East Online, 10 September 2012, http://www.middle-eastonline.com/english/?id=54286

Hosna A. (2007), ‘Accords d'Evian : processus d'une formation identitaire', Revue Sciences Humaines, June 2007, pp. 5-18

Le Foll-Luciani P.J. (2012), ‘Algériens non-musulmans à l'épreuve de l'indépendance', La vie des idées.fr, 2 April 2012

Mahiou A. (2005), “La nationalité en Algérie”, in Regards critiques et perspectives sur 
le droit et la fiscalité, Liber Amicorum Cyrille David, Paris: LGDJ, pp. 395-407

Parolin G. (2009), Citizenship in the Arab world: Kin, Religion and Nation State, Amsterdam: Amsterdam University Press

Perrin D. (2011a), 'Immigration and Citizenship Law in the Maghreb - Turning Aliens into Citizens', EUI Working Paper, RSCAS 2011/40, EUDO Citizenship Observatory Perrin D. (2011b), Citizenship in Morocco - National Report, EUDO Citizenship Report, RSCAS EUDO-CIT CR 2011/42, EUI.

Perrin D. (2009), "Beyond the borders: Dual nationality in Western Mediterranean Countries", in Schäfer I. and Henry J.R. (eds.), Mediterranean policies from above and from below, Baden-Baden: Nomos, pp. 537-561

Perrin D. (2007), “Identité et transmission du lien national au Maghreb. Etude comparée des codes de la nationalité", L'Année du Maghreb, pp. 479-497 